\title{
PENINGKATAN SIKAP PEDULI SOSIAL DAN PRESTASI BELAJAR MATA PELAJARAN PENDIDIKAN KEWARGANEGARAAN MELALUI MODEL KOOPERATIF TIPE STAD
}

\author{
Sitirah \\ SD Negeri 02 Kedungwuluh Kidul. Banyumas, Indonesia \\ Email: sitirah25@gmail.com
}

\begin{abstract}
The background of this research is the lack of social care attitude and student's achievement. This research is aimed to increase the social care attitude and student's achievement in PKn (Civic) subject in material of globalisation effect through cooperative learning model of ( Student Teams Achievement Division)STAD type. The subject of research is the students of $4^{\text {th }}$ grader of SD 02 Kedungwuluh Kidul with the total number of student are 16. Class action research was held in two cycles. Each of cycle consists of two meetings, one meeting consists of two hours. The procedure of each cycle included planning, action, observation, and reflection. The data collection was gotten from teacher's observation and students' activity report. To know the students' social attitude, the researcher used social care attitude questionnaire. While to get the data of students' achievement, the researcher used the evaluation sheet at the end of each cycle. Based on the research of social care attitude in cycle I, it was shown that the average was 3,20 and the percentage was 80,15\% and from Cycle II, the average was 3,67 and the percentage was 91,87\%. The result of achievement scoring from cycle I, the class average was 72,81 with the percentage $81,25 \%$ and from cycle II was got the class average was 86,87 with percentage $100 \%$. From those results, can be concluded that cooperative learning method (Student Teams Achievement Division)STAD type can enhance the social attitude care and students achievement of PKn of class IV SD 02 Kedungwuluh Kidul.
\end{abstract}

Keywords: Social care Attitude, Achievent, PKn (Civic), Cooperative STAD type

Abstrak. Meningkatkan Sikap Peduli Sosial Siswa dan Prestasi Belajar di PKn melalui Cooperative STAD (Student Teams Achievement Division) Model Siswa Kelas IV SD Negeri 02 Kedungwuluh Kidul. Latar belakang penelitian ini adalah kurangnya sikap kepedulian sosial dan prestasi siswa. Penelitian ini bertujuan untuk meningkatkan sikap kepedulian sosial dan prestasi belajar siswa pada mata pelajaran PKn (Civic) dalam materi efek globalisasi melalui model pembelajaran kooperatif tipe Student Teams Achievement Division (STAD). Subjek penelitian adalah siswa kelas IV SD 02 Kedungwuluh Kidul dengan jumlah siswa 16 siswa. Penelitian tindakan kelas dilaksanakan dalam dua siklus. Setiap siklus terdiri dari dua pertemuan, satu pertemuan terdiri dari dua jam. Prosedur setiap siklus termasuk perencanaan, tindakan, observasi, dan refleksi. Pengumpulan data diperoleh dari observasi guru dan laporan aktivitas siswa. Untuk mengetahui sikap sosial siswa, peneliti menggunakan kuesioner sikap peduli sosial. Sementara untuk mendapatkan data prestasi siswa, peneliti menggunakan lembar evaluasi pada akhir setiap siklus. Berdasarkan penelitian sikap kepedulian sosial pada siklus I, ditunjukkan bahwa rata-rata adalah 3,20 dan persentase adalah $80,15 \%$ dan dari Siklus II, rata-rata 3,67 dan persentase adalah $91,87 \%$. Hasil penilaian prestasi dari siklus I, rata-rata kelas adalah 72,81 dengan persentase $81,25 \%$ dan dari siklus II didapatkan rata-rata kelas 86,87 dengan persentase $100 \%$. Dari hasil tersebut, dapat disimpulkan bahwa metode pembelajaran kooperatif (Student Teams Achievement Division) tipe STAD dapat meningkatkan sikap peduli sosial dan prestasi belajar PKn siswa kelas IV SD 02 Kedungwuluh Kidul.

Kata kunci: Sikap kepedulian sosial, Pencapai, PKn (Civic), tipe STAD kooperatif 


\section{PENDAHULUAN}

Peningkatan kualitas mutu pendidikan merupakan hal yang sangat penting untuk menciptakan kehidupan yang cerdas, damai, terbuka dan demokratis. Oleh karena itu sangat penting dilakukan upaya pembaharuan di bidang pendidikan sehingga akan tercapai kualitas pendidikan sesuai dengan tujuan pendidikan nasional yang termuat dalam UUSPN No. 20 tahun 2003, sebagai berikut: Pendidikan adalah usaha sadar dan terencana untuk mewujudkan suasana belajar dan proses pembelajaran agar peserta didik secara aktif mengembangkan potensi dirinya untuk memiliki kekuatan spiritual keagamaan, pengendalian diri, kepribadian, kecerdasan, akhlak mulia, serta keterampilan yang diperlukan dirinya, masyarkat, bangsa dan negara.

Pelaksanaan pendidikan di sekolah dasar terdapat dalam pembelajaran. Kegiatan ini sangat tergantung dari cara guru dalam merangcang pembelajaran sehingga dapat mencapai tujuan yang diharapkan sesuai dengan standar kompetensi dan kompetensi dasarnya. Hal ini juga didukung dengan persepsi umum yang menyoroti bahwa merupakan tugas guru untuk mengajar dan menyoroti siswa dengan berbagai muatan informasi dan pengetahuan.

Mencapai tujuan tersebut tentu bukan pekerjaan yang mudah untuk dicapai. Kondisi demikian juga terjadi pada siswa kelas IV SD Negeri Kedungwuluh Kidul Kecamatan Patikraja. Berdasarkan data awal, diketahui bahwa pada pembelajaran PKn terdapat materi yang belum bisa dicapai siswa denga optimal, yaitu Standar Kompetensi menunjukkan "sikap kita terhadap globalisasi" di lingkungannya dengan Kompetensi Dasar mengidentifikasi jenis budaya Indonesia yang pernah ditampilkan dalam misi kebudayaan internasional. Data 2 (dua) tahun pelajaran terakhir, menunjukkan data sebagai berikut:

Tabel 1

Hasil Ketuntasan Belajar Mata Pelajaran PKn Materi "Sikap Kita Terhadap Globalisasi"

\begin{tabular}{|l|l|l|}
\hline Kriteria & $2011 / 2012$ & $2012 / 2013$ \\
\hline Jumlah Siswa & 22 & 21 \\
\hline KKM & 65 & 65 \\
\hline Tuntas Belajar & 14 & 12 \\
\hline
\end{tabular}

Dari data pada tabel 1 menunjukkan bahwa secara keseluruhan menunjukkan bahwa pada tahun ajaran 2011/2012 dan 2012/2013 masih banyak siswa yang belum mencapai KKM yang diharapkan. Kondisi tersebut tentu merupakan keprihatinan tersendiri. Untuk mencari tahu penyebab rendahnya ketunasan belajar siswa, maka dilakukan observasi awal terhadap pelaksanaan kegiatan pembelajaran $\mathrm{PKn}$ materi "sikap kita terhadap globalisasi" pada hari Selasa tanggal 18 Pebruari 2014.

Dari hasil observasi awal, diperoleh catatan bahwa selama pelaksanaan kegiatan pembelajaran guru tampak sudah menjelaskan materi secara runtut, guru juga sudah memberikan kesempatan kepada siswa untuk bertanya tentang hal-hal yang diketahui dan memberikan kesempatan kepada siswa yang belum paham untuk bertanya. Sesekali guru juga menggunakan 
media sebagai alat bantu berupa media gambar. Dari kegiatan tersebut, setelah dilakukan evaluasi pendahuluan diperoleh data dari jumlah siswa yang tuntas belajar dengan memperoleh nilai sesuai KKM yaitu 70 dari 16 siswa atau 57,14\%, jumlah yang sudah mencapai nilai KKM baru 8 siswa atau $50 \%$. Dari hasil observasi tersebut, tampak bahwa penyebab rendahnya kemampuan siswa dalam menyerap materi bukan pada guru namun pada metode yang digunakan. Hal tersebut karena selama kegiatan pembelajaran, guru lebih banyak menuntut siswa untuk mendengarkan. Selain itu siswa juga kurang aktif, bahkan siswa tampak takut-takut saat mau bertanya baik pada guru maupun pada teman sebangkunya sehingga komunikasi antar guru dengan siswa dan siswa dengan siswa menjadi kurang terjalin.

Padahal sangat penting jika siswa dibiasakan untuk bertukar pikiran melalui komunikasi yang baik antar siswa agar bisa saling mengisi satu sama lain. Tingkat sikap peduli sosial atau kepedulian terhadap teman yang nilainya kurang oleh siswa yang nilainya bagus masih harus ditingkatkan lagi dengan menumbuhkan rasa empati sehingga anak memiliki kemauan untuk membantu temannya melalui belajar kelompok ataupun diskusi. Rendahnya sikap peduli sosial tampak pada adanya siswa yang egois, tidak mau bekerja sama dan tidak peduli siswa yang merasa kesulitan.

Pada pelaksanaan kegiatan pembelajaran, guru harus dapat memilih dan menggunakan beberapa pendekatan pembelajaran. Banyak pendekatan yang digunakan guru yang masing-masing memiliki kelebihan dan kekurangan, kekurangan satu strategi dapat ditutupi dengan yang lain sehingga guru dapat menggunakan beberapa metode mengajar dalam melakukan proses belajar mengajar, namun demikian pemilihan strategi pembelajaran perlu memperhatikan suatu materi yang disampaikan, tujuan pembelajaran, waktu yang tersedia dan banyaknya siswa serta hal-hal yang berkaitan dengan proses belajar mengajar.

Salah satu alternatif yang dapat dipilih adalah dengan menyelenggarakan kegiatan pembelajaran kooperatif tipe STAD. Pembelajaran kooperatif sesuai dengan fitrah manusia sebagai makhluk sosial yang penuh ketergantungan dengan orang lain, mempunyai tujuan dan tanggung jawab bersama, pembagian tugas, dan rasa senasib. Saling membantu dan berlatih berinteraksikomunikasi-sosialisasi karena kooperatif merupakan miniatur dari hidup bermasyarakat, dan belajar menyadari kekurangan dan kelebihan masing-masing.

STAD merupakan salah satu tipe model pembelajaran kooperatif yang paling sederhana, dan merupakan pendekatan yang baik untuk permulaan bagi para guru yang baru mengguakan pendekatan kooperatif (Slavin, 2005: 143). Teknik ini memberi siswa kesempatan menunjukkan kepeduliannya kepada temannya yang belum mampu menguasai materi dengan baik. Melalui tipe STAD ini maka siswa akan saling bantu satu sama lain dan berusaha mengembangkan kemampuan temannya yang belum bisa. Keunggulan lain dari teknik ini adalah menumbuhkan sikap peduli dengan teman atau orang lain.

Penelitian tentang penerapan pendekatan tipe STAD pernah dilakukan oleh Epi Yuni dengan Judul Model Pembelajaran STAD untuk Meningkatkan Hasil Belajar Siswa Kelas IV Mata Pelajaran PKn di SDN Lesanpuro 3 Kota Malang. Dari penelitian tersebut menyimpulkan bahwa STAD dapat 
meningkatkan hasil belajar siswa kelas IV SDN Lesanpuro 3 Kota Malang. Penelitian tersebut menunjukkan bahwa pembelajaran tipe $S T A D$ pernah diterapkan pada pembelajaran PKn dan mampu mengatasi permasalahan rendahnya hasil belajar siswa.

Mengacu pada uraian di atas, penelitian ini dilakukan untuk meningkatkan kepedulian sosial dan prestasi belajar mata pelajaran Pendidikan Kewarganegaraan materi "sikap kita terhadap globalisasi" melalui pelaksanaan penelitian tindakan kelas dengan menerapkan model pembelajaran kooperatif tipe STAD pada siswa kelas IV SD Negeri Kedungwuluh Kidul Kecamatan Patikraja Tahun Ajaran 2013/2014.

\section{Pendidikan Karakter Bangsa}

Pendidikan karakter itu merupakan upaya-upaya yang dirancang dan dilaksanakan secara sistematis untuk membantu peserta didik memahami nilainilai perilaku manusia yang berhubungan dengan Tuhan Yang Maha Esa, diri sendiri, sesama manusia, lingkunga, dan kebangsaan yang terwujud dalam pikiran, sikap, perasaan, hukum, tara karma, budaya, dan adat istiadat (Wibowo, 2012: 48).

Narwati (2011: 14), memberikan penjelasan bahwa pendidikan karakter adalah suatu sistem penanaman nilai-nilai karakter kepada warga sekolah yang meliputi komponen pengetahuan, kesadaran atau kemauan, dan tindakan untuk melaksanakan nilai-nilai tersebut, baik terhadap Tuhan Yang Maha Esa (YME), diri sendiri, sesama, lingkungan, maupun kebangsaan sehingga menjadi manusia insan kamil. Selanjutnya dikemukakan bahwa pendidikan karakter memiliki esensi dan makna yang sama dengan pendidikan moral dan pendidikan akhlak. Tujuannya adalah membentuk pribadi anak, supaya menjadi manusia yang baik, warga masyarakat, dan warga negara yang baik. Adapun kriteria manusia yang baik, warga masyarakat yang baik, dan warga negara yang baik bagi suatu masyarakat atau bangsa, secara umum adalah nilai-nilai sosial tertentu, yang banyak dipengaruhi oleh budaya masyarakat dan bangsanya.

\section{Peduli Sosial}

Pada pelaksanaan penelitian ini, karakter bangsa yang akan ditingkatkan dengan mengacu pada kondisi riil yang terjadi di lingkungan pembelajaran adalah integritas atau sikap peduli. Nilai peduli yang dikembangkan adalah integritas yaitu nilai peduli sosial. Nilai peduli sosial adalah sikap dan tindakan yang selalu ingin memberi bantuan pada orang lain dan masyarakat yang membutuhkan (Agus Wibowo, 2012: 44).

\section{Prestasi}

Prestasi belajar adalah harapan bagi setiap siswa yang sedang mengikuti proses pembelajaran di sekolah serta harapan bagi wali murid dan guru. kata prestasi belajar adalah suatu pengertian yang terdiri atas dua kata yaitu prestasi dan kata belajar, dimana masing-masing mempunyai arti berbeda. Prestasi belajar dapa didefinisikan seberapa jauh hasil yang sudah didapat siswa dalam penguasaan tugas-tugas atau matei pelajaran yang diterima dalam waktu tertentu.

Menurut Bustalin (2004: 3), prestasi adalah penilaian pendidikan tentang perkembangan dan kemajuan murid yang berkenaan dengan penguasaan bahan pelajaran yang disajikan kepada mereka dan nilai-nilai yang terdapat dalam kurikulum. Selanjutnya didefinisikan oleh Bustalin (2004: 11) bahwa prestasi belajar siswa merupakan hasil yang diperoleh dari proses belajar mengajar. Prestasi belajar siswa adalah perubahan dalam hal kecakapan tingkah laku ataupun kemampuan yang dapat bertambah selama beberapa waktu dan tidak disebabkan oleh proses pertumbuhan, tetapi adanya situasi belajar, perwujudan dalam bentuk hasil proses belajar tersebut dapat berupa pemecahan lisan atau tulisan, dan keterampilan serta pemecahan masalah yang 
langsung dapat diukur atau dinilai dengan menggunakan tes-tes yang berstandar.

\section{Kewarganegaraan}

Pendidikan

Kewarganegaraan

merupakan salah satu dari lima tradisi

Pendidikan Ilmu Pengetahuan Sosial yakni citizenship transmission, saat ini sudah berkembang menjadi tiga aspek pendidikan kewarganegaraan (citizenship education), yakni aspek akademis, aspek kurikuler, dan aspek sosial budaya. Secara akademis pendidikan kewarganegaraan dapat didefinisikan sebagai suatu bidang kajian yang memusatkan pembahasan pada seluruh dimensi psikologis dan sosial budaya kewarganegaraan individu, dengan menggunakan ilmu politik, ilmu pendidikan sebagai landasan kajiannya ataupun penemuan intinya yang diperkaya dengan disiplin ilmu lain yang relevan, dan mempunyai implikasi kebermanfaatan terhadap instrumentasi dalam sistem pendidikan nasional (Udin S. Winataputra dalam Depdiknas, 2008: 8).

Pendidikan Kewargaan menurut Azra (dalam Tukiran Taniredja, 2009: 2), adalah pendidikan yang cakupannya lebih luas daripada Pendidikan Demokrasi dari Pendidikan HAM. Karena, Pendidikan Kewargaan mencakup kajian dari pembahasan tentang pemerintahan, konstitusi dan lembaga-lembaga demokrasi, rule of law, hak dan kewajiban warga negara, proses demokrasi, partisipasi aktif dan keterlibatan warga negara dalam masyarakat madani, pengetahuan tentang lembaga-lembaga dan sistem yang terdapat dalam pemerintahan, warisan politik, administrasi publik dan sistem hukum, pengetahuan tentang proses seperti kewarganegaraan aktif, refleksi kritis, penyelidikan dan kerja sama, keadilan sosial, penegrtian antar budaya dan kelestarian lingkungan hidup dan hak asasi manusia.

\section{Materi Globalisasi}

Ada beberapa sikap yang harus dimiliki oleh bangsa yang bermartabat dan memiliki jati diri yang luhur, diantaranya sebagai berikut:

1. Mempertebal keimanan dan meningkatkan ketakwaan terhadap Tuhan Yang Maha Esa.

2. Ikut berperan dalam kegiatan organisasi keagamaan dalam mengatasi perubahan.

3. Belajar dengan giat untuk menguasai ilmu pengetahuan dan teknologi agar dapat berperan maksimal dalam menjalani era globalisasi.

4. Mencintai dan menggunakan produk dalam negeri.

5. Mencintai kebudayaan bangsa sendiri dari pada kebudayaan asing.

6. Melestarikan budaya bangsa dengan mempelajari dan menguasai kebudayaan tersebut, baik seni maupun adat istiadatya.

7. Memilih informasi dan hiburan dengan selektif agar menjaga dari pengaruh negatif.

8. Menjauhi kebiasaan buruk gaya hidup dunia barat yang bertentangan nilai dan norma yang berlaku, seperti meminum minuman keras, menggunakan narkotika dan obat-obatan terlarang, dan pergaulan bebas.

Agar tetap memiliki kepribadian sebagai bangsa Indonesia, perlu mengamalkan nilai-nilai Pancasila. Pancasila merupakan cerminan dari nilai-nilai budaya bangsa yang dapat diterima oleh semua kalangan. Nilai-nilai Pancasila yang amalkan dapat mencegah pengaruh negatif dari globalisasi.

Teknik Kooperatif STAD 
Model pembelajaran kooperatif adalah salah satu model pembelajaran yang menempatkan siswa sebagai subjek pembelajaran (student oriented). Dengan suasana kelas yang demokratis, yang saling membelajarkan memberikan kesempatan peluang lebih besar dalam memberdayakan potensi siswa secara maksimal.

Pembelajaran kooperatif (cooperative learning) diyakini sebagai praktik pedagogis untuk meningkatkan proses pembelajaran, gaya berpikir bertingkat-tingkat, perilaku sosial, sekaligus kepedulian terhadap siswasiswa yang memiliki latar belakang kemampuan, penyesuaian, dan kebutuhan yang berbeda-beda. Bahkan Johnson, dkk (2000) menegaskan bahwa kecuali pembelajaran kooperatif, tidak ada satupun praktik pedagogis yang secara siultan mampu memenuhi tujuan beragam seperti ini (Miftahul Huda, 2011: 27).

STAD di kembangkan oleh Robert E. Slavin (2005: 143) merupakan salah satu tipe pembelajaran kooperatif yang paling sederhana sehingga tipe ini dapat digunakan oleh guru-guru yang baru mulai pendekatan pembelajaran kooperatif. Pada pembelajaran kooperatif tipe STAD siswa dapat ditempatkan dalam kelompok belajar yang beranggotakan empat sampai lima orang yang merupakan campuran menurut tingkat kinerja, jenis kelamin dan suku. Guru menyajikan pelajaran dan kemudian siswa bekerja dalam kelompoknya untuk memastikan bahwa seluruh anggota kelompoknya telah menguasai materi pelajaran tersebut. Akhirnya kepada seluruh siswa diberikan test tentang materi pelajaran tersebut.

\section{METODE PENELITIAN}

Penelitian ini merupakan Penelitian Tindakan Kelas (PTK). Metode tes yaitu metode dan instrumen pengumpulan data dengan menggunakan serentetan pertanyaan atau latihan, serta alat lain yang digunakan untuk mengukur ketrampilan, pengetahuan intelegensi, kemampuan atau bakat yang dimiliki oleh individu dan kelompok. Tes yang digunakan dalam penelitian ini meliputi: Tes lisan dilakukan di awal, tengah, dan akhir kegiatan pembelajaran dan tes tertulis dilakukan pada akhir kegiatan pembelajaran yaitu pada tiap akhir pelaksanaan siklus pada pertemuan kedua. Tempat pelaksanaan penelitian tindakan kelas ini adalah SD Negeri Kedungwuluh Kidul Kecamatan Patikraja Kabupaten Banyumas. Penelitian ini dilaksanakan selama 4 bulan pada semester Genap yaitu bulan Maret - Juni 2014.

Subyek penelitian ini adalah siswa kelas IV SD Negeri Kedungwuluh Kidul Kecamatan Patikraja Kabupaten Banyumas yang berjumlah 16 siswa terdiri dari 5 siswa dan 11 siswi. Sedangkan partisipan dalam penelitian ini adalah guru kelas IV yang berkolaborator dengan peneliti yang dinilai memahami tentang pembelajaran Pendidikan Kewarganegaraan. Kegiatan PTK ini dilakukan langsung oleh peneliti dan diamati oleh observer.

\section{Tabel 1.}

Hasil aktivitas siswa selama dua siklus

\begin{tabular}{|l|l|l|l|l|}
\hline Siklus & Jumlah & Persentase & Rata-rata & Kriteria \\
\hline I & 819 & $91,40 \%$ & 3,2 & Baik \\
\hline II & 858 & $95,75 \%$ & 3,83 & Sangat Baik \\
\hline
\end{tabular}

Hasil aktivitas siswa dengan model achievement division (STAD) menunjukkan adanya peningkatan sebesar $4,35 \%$ yaitu pembelajaran dengan student teams- 
pada siklus I sebesar 91,40\% menjadi 95, 75 $\%$ pada siklus II.

\section{Hasil prestasi belajar siswa}

Data nilai prestasi belajar siswa diperoleh dari nilai ulangan yang dilaksanakan pada pertemuan kedua atau akhir siklus. Bentuk soal ulangan berupa soal uraian yang dibuat berdasarkan indikator pembelajaran yang telah disampaikan oleh guru pada pertemuan pertama dan kedua setiap siklusnya.

Berdasarkan hasil penelitian diperoleh bahwa prestasi belajar siswa mengalami peningkatan dari siklus I hingga siklus II. Persentase nilai rata-rata hasil evaluasi prestasi belajar PKn kelas IV SD 04 Kedungwuluh Kidul dapat dilihat pada Tabel

Tabel 2

\section{Hasil Peningkatan Prestasi Belajar Siswa Kelas IV SD N 02 Kedungwuluh Kidul selama dua siklus}

\begin{tabular}{|l|l|l|l|l|l|}
\hline No & Siklus & Tuntas & $\begin{array}{l}\text { Tidak } \\
\text { Tuntas }\end{array}$ & $\begin{array}{l}\text { Rata-rata } \\
\text { Nilai }\end{array}$ & $\begin{array}{l}\text { Persentase } \\
\text { Ketuntasan }\end{array}$ \\
\hline $\mathbf{1}$ & I & 13 & 3 & 72,81 & $81,25 \%$ \\
\hline $\mathbf{2}$ & II & 16 & 0 & 86,87 & $100 \%$ \\
\hline
\end{tabular}

Berdasarkan tabel hasil rekapitulasi selama dua siklus dapat dilihat ada peningkatan hasil setiap siklus, yaitu dari $81,25 \%$ pada siklus I menjadi $100 \%$ pada siklus II. Diketahui adanya peningkatan persentase nilai prestasi belajar sebesar $18,75 \%$ dengan menggunakan model pembelajaran dengan student teamsachievement division (STAD). Pada siklus I siswa yang tidak tuntas berjumlah 3 siswa dari jumlah 16 siswa, sedangkan siswa yang tuntas berjumlah 13 siswa atau sekitar $81,25 \%$ dari jumlah seluruh siswa, sedangkan pada siklus II siswa yang tuntas 16 siswa dari 16 siswa. Peningkatan ini sesuai dengan indikator keberhasilan yaitu terlihat pada siklus II yang mencapai persentase nilai ratarata sebesar $100 \%$.

\section{Sikap Peduli Sosial Siswa}

Berdasarkan hasil rekapitulasi angket rasa ingin tahu siswa dari siklus I dan II mengalami peningkatan, hasil peningkatan sikap peduli siswa dapat dilihat pada Tabel 3.

Berdasarkan tabel hasil rekapitulasi angket sikap peduli sosial siswa selama dua siklus dapat dilihat ada peningkatan hasil setiap siklus, yaitu dari $80,15 \%$ pada siklus I menjadi $91,87 \%$ pada siklus II.

Tabel 3.

Sikap Peduli Sosial siswa selama dua siklus

\begin{tabular}{|l|l|l|l|l|}
\hline Siklus & Jumlah & Persentase & Rata-rata & Kriteria \\
\hline I & 513 & $80,15 \%$ & 3,20 & Baik \\
\hline II & 588 & $91,87 \%$ & 3,67 & Sangat baik \\
\hline
\end{tabular}


Berdasarkan tabel dan gambar di atas diketahui adanya peningkatan persentase nilai angket sikap peduli sosial siswa, yaitu sebesar $11,72 \%$. Pada siklus I, ditunjukan nilai angket rasa ingin tahu siswa sebesar $80,15 \%$ menjadi $91,87 \%$ pada siklus ke II.

\section{SIMPULAN DAN SARAN}

Penggunaan Model Pembelajaran kooperatif tipe student teams-achievement division (STAD) dapat meningkatkan aktivitas siswa. Hal tersebut ditunjukan adanya peningkatan persentase dengan perolehan rata-rata aktivitas siswa pada siklus I sebesar 91, $49 \%$ dan siklus II $95,75 \%$. Berdasarkan hasil penilitian dapat disimpulkan sebagai berikut:

1. Penggunaan model pembelajaran kooperatif tipe student teams-achievement division (STAD) ternyata dapat pula meningkatkan sikap peduli sosial siswa. Hal ini ditunjukkan dengan adanya peningkatan persentase nilai sikap peduli sosial siswa sebesar $11,72 \%$ dari nilai siklus I sebesar $81,15 \%$, menjadi $91,87 \%$ pada siklus II.

2. Penggunaan model pembelajaran kooperatif tipe student teamsachievement division (STAD) dapat meningkatkan prestasi belajar siswa. Hal ini ditunjukkan adanya peningkatan persentase nilai prestasi siswa sebesar 8 , $75 \%$ dari nilai siklus I sebesar 81,25\% menjadi $100 \%$ pada siklus II.

Berdasarkan hasil penelitian tindakan kelas yang telah dilaksanakan di kelas IV SD N 02 Kedungwuluh Kidul, peneliti memberikan beberapa saran yaitu:

1. Penggunaan model pembelajaran kooperatif tipe student teams-achievement division (STAD) dapat dijadikan pembelajaran alternative khususnya pada mapel PKn materi dampak globalisasi

2. Penggunaan model pembelajaran kooperatif tipe student teams-achievement division (STAD) memerlukan waktu dan kegiatan yang cukup lama sehingga guru hendaknya bisa memadukan waktu yng tersedia dengan materi yang akan diajarkan, agar tujuan pembelajaran tercapai maksimal.

\section{DAFTAR PUSTAKA}

Agus W., 2012. Pendidikan Karakter. Jogjakarta: Pustaka Pelajar.

Amin, M. 2011. Panduan Praktis Penelitian Tindakan Kelas. Sleman: Inspirasi.

Ahmadi, A. 2010. Psikologi Belajar. Jakarta: Rineka Cipta.

Arikunto, S. 1998. Prosedur Penelitian Suatu Pendekatan Praktek. Jakarta: Bumi Aksara.

Djamarah, S. B. 2002. Psikologi Belajar. Jakarta:Rineka Cipta.

Depdiknas. 2006. Kurikulum Tingkat Satuan Pendidikan. Jakarta.

Dimyati dan Mudjiono, 2006. Belajar dan Pembelajaran. Jakarta: Rineka Cipta.

Huda, M. 2011. Cooperative Learning. Jogjakarta: Pustaka Pelajar.

Lie, A. 2008. Cooperative Learning. Jakarat: Grasindo.

Mulyasa. 2010. Kurikulum Tingkat Satuan Pendidikan. Bandung: Remaja Rosdakarya.

Narwati, S. 2010. Pendidikan Karakter Pengintegrasian 18 Nilai Pembentuk Karakter dalam Mata Pelajaran. Yogyakarta: Familia.

Nurhadi, dkk. 2003. Pembelajaran Konstekstual (Cooperatif Learning di Ruang-ruang Kelas) Jakarta: Gramedia Widiasarana.

Purwanto, N. 2010. Prinsip-prinsip dan teknik Evaluasi Pengajaran. Bandung : PT Remaja Rosdakarya.

Sagala, S. 2010. Makna dan Konsep Pembelajaran. Bandung: Alfabeta.

Slameto. 2003. Belajar dan Faktor-faktor yang Mempengaruhinya. Jakarta: RinekaCipta.

Slavin, 2005. Cooperative Learning. Bandung: Nusa Media.

Sri N., 2012. Pendidikan Karakter. Yogyakarta: Familia. 
Taniredja, T. 2011. Model-model

Pembelajaran Inovatif. Bandung: Alfabeta. 